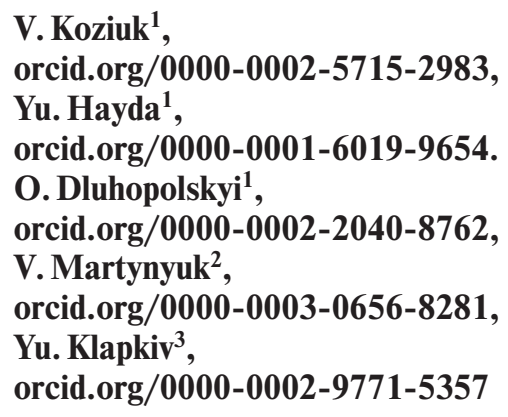

1 - Ternopil National Economic University, Ternopil, Ukraine, e-mail: dlugopolsky77@gmail.com

2 - University of Economics and Innovation (WSEI), Lublin, Poland

3 - University of Lodz, Lodz, Poland

\title{
EFFICIENCY OF ENVIRONMENTAL TAXATION IN EUROPEAN COUNTRIES: COMPARATIVE ANALYSIS
}

Purpose. To make an economic assessment of the effectiveness of the environmental tax system in European countries. The hypothetical question is how and when changes in (increasing or decreasing) the rates of different types of environmental taxes affect the pollution of the environment.

Methodology. To evaluate economically the effectiveness of the environmental taxation system, the article uses the method of cross-correlation between indicators in European countries.

Findings. The effectiveness of environmental taxes depends on the tax base, tax rates, the evolution of taxes, and tax policy. The design of environmental taxes and their implementation differs across countries within the EU. According to the research conducted, two groups of countries can be distinguished in the EU taking into account polar trends of environmental taxation development. The first group of the countries shows the downward trend in environmental taxes - the annual average of the total environmental tax revenue in these countries today is below its base value in 2008 (Bulgaria, Cyprus, Norway, Luxembourg, Slovenia, Hungary, Croatia, Sweden, Iceland, Malta, Estonia, Latvia, Lithuania). The second group of the countries shows a clear upward trend in environmental taxes ranging (Denmark, Greece, Switzerland, the United Kingdom, Italy, Belgium, Germany, Finland, Spain, the Netherlands, Austria, France, Poland).

Originality. Depending on the time lag symbol and the direction of cross-correlation, there are four groups of countries within the environmental policy. The first cluster includes countries in which environmental policy instruments such as air pollution fees and resource use charges are quite effective (Poland, Slovakia, Slovenia, Estonia). The second cluster includes countries in which the environmental tax increase was accompanied by an increase in $\mathrm{CO}_{2}$ emissions (Belgium, the Czech Republic, Finland, Hungary). In the third group of countries deterioration of the environmental situation is not a motivator for increasing the environmental taxation burden (Lithuania, Greece). The fourth cluster demonstrates that deterioration of the environmental situation in the country motivates to increase the environmental taxation burden (Bulgaria, Spain).

Practical value. The data obtained indirectly indicate that the dependencies between the time series we investigated are likely to be nonlinear in nature, which the found cross-correlation coefficients cannot detect. The research demonstrates the high probability of the existence of diametrically opposite interdependencies between the studied variables for different groups of countries.

Keywords: environmental taxation, environmental policy, economic growth, EU member states

Introduction. Threatening trends of deterioration of the current state of the environment on a global level, caused by the effects of economic agents, excessive consumption of government and householders necessitate the development of effective environmental policy. Such a policy in the context of environmental taxes and its adequate institutional support should help the society to achieve the priority of providing the "clean ecology" as public good.

In recent decades, the intensive use of natural resources has demonstrated persistent threatening trends in the ability to produce the required amount of goods. The classic problem of the mismatch of total social needs, on the one hand, and the resources available for their provision, on the other, not only has retained its relevance; it also has acquired particular institutional acuity and planetary significance. Considering this, environmental protection is one of the priority areas in state administration [1]. All the countries of the EU use several important economic levers in the form of environmental taxes, fees and charges, trade permits, subsidies, and deposit repayment systems) to achieve important environmental policy goals.

In the EU, there are several challenges to the Environmental Tax Reform (ETR), and many of them are capable of influencing household behavior. Low-income households are par-

(C) Koziuk V., Hayda Yu., Dluhopolskyi O., Martynyuk V., Klapkiv Yu., 2020 ticularly sensitive in this context. Some EU countries are pursuing policies that are based on "tax punishment" or aimed at raising additional funds to invest in environmental issues. The system of environmental taxes in the sense of improving the efficiency and protection of natural resources includes energy tax (ET), transport tax (TT), pollution tax (PT) and resource $\operatorname{tax}(\mathrm{RT})$

Literature review. The theoretical background of environmental taxation is based on the A. Pigou concept about using taxation to correct negative externalities, such as pollution [2]. Taxation is a powerful tool for tackling complex environmental issues such as climate change [3]. This is especially true for developed and developing countries, since environmental taxation itself is a significant element of economic growth [4, 5]. However, lobbying for environmental taxes is often not successful for many reasons [6].

Efficiency and public perception itself are factors that hinder widespread implementation of environmental taxation [7]. The importance of taxation as a tool to change environmental behavior is directly dependent on its effectiveness [8]. When tax revenues are used for environmental expenditures or other taxes, these taxes are considered effective and officially supported [9]. Although direct impact factors are still under study, some have already been addressed such as instrumental coerciveness and psychological factors, or fiscal illusion [10].

In case of force majeure circumstances, the main costs are borne by the state, bypassing the possibilities of the financial 
mechanism of insurance [11], or providing application of the latest financial instruments. Ensuring overall well-being requires maintaining an environmental component [12, 13], which is accompanied by significant expenditures from the state budget.

At the same time, assertions about the dualism of dividends from environmental taxation are often dominant [14]. The modern development of civilization is increasingly paying attention to education and taxation, as an element of financing measures aimed at improving the environmental situation $[15,16]$.

Purpose. The purpose of the article is to make an economic assessment of the effectiveness of the environmental tax system. The hypothetical question is how and when changing (increasing or decreasing) the rates of different types of environmental taxes affects the pollution of the environment. So, it is advisable to analyze the specifics of tools of the environmental policy of countries that have significant experience in this field. In particular, the cases of the European countries, which use a number of effective economic levers in the form of environmental taxes, charges, trade permits, subsidies, and so on, are seen as indicative of the introduction of an effective environmental taxation system.

Methods. To evaluate economically the effectiveness of the environmental taxation system, the article uses the method of cross-correlation between indicators in every country of Europe.

Results. Economic assessment of energy taxes, transport taxes, pollution taxes and resource taxes in the EU countries. In the EU, economic levers, including tax policies, are designed to ensure that the environmental targets can be achieved at the national level. The effectiveness of economic instruments depends on the selectivity of their choice. EU is positioning itself as a world leader in the design, enforcement, and implementation of a rigorous environmental policy. Against this background, the conduct of ETRs, as well as changes in climatic conditions, raises concerns in terms of the impact on employment, export volumes, income sharing, and economic growth. Sweden, in conjunction with other Northern countries (Denmark, Finland, Norway and the Netherlands), was one of the first to implement the ETR in the 1990s. The main objective of these reforms was to lower the labor tax [17]. Environmental fiscal reforms have been gradually introduced in European countries since April 1, 1999. Further steps in this direction were made in 2000 and 2003. In Germany, the main objective of environmental fiscal reform was to reduce energy consumption and, consequently, reduce harmful emissions, and promote the development of new technologies and investment in innovation. The state budget income from these tax revenues was used to reduce pension contributions [18]. The result of this ETR was the creation of a significant number of new jobs (about 250.000 in 2003), representing $0.75 \%$ of their total current amount [1].

Since 2010, the emphasis on environmental regulation has shifted towards the EU 2020 strategy, the main goal of which is to achieve greater consistency in the implementation of economic, social, and environmental programs. In general, the EU 2020 strategy is based on five key objectives [19]:

- achieving the level of employment, which is $75 \%$ of the working-age population;

- ensuring investment in research and innovation at $3 \%$ of the EU's GDP;

- ensuring the proportionality of " $20 / 20 / 20$ " in climate conservation and energy use, respectively, as a result of reducing greenhouse gas emissions by at least $20 \%$, achieving the same share of final energy consumption from renewable sources and energy adequacy;

- raising the level of education through the involvement of children who do not attend school, and increasing the share of the population with a higher, or equivalent, level of education;

- promoting social inclusion, including poverty reduction.
The effectiveness of environmental taxes depends on several components, namely, tax bases, tax rates, evolution of taxes, and tax policy. The design of environmental taxes (e.g. tax rate, purpose/aim, breadth of coverage) and their implementation differs across countries within the EU. Some states focus on a narrower set of taxes, while others take a broader approach [18]. Most EU countries, for example, use vehicle taxes as one of the most important environmental policy instruments in pursuit of climate change prevention. Lithuania and Estonia are the only two countries that do not apply vehicle taxes. Poland and Bulgaria use this type of tax, but without $\mathrm{CO}_{2}$ and fuel efficiency differentiation. In terms of the European Commission, these four countries have the potential to expand their tax bases precisely through vehicle taxes, which would, at the same time, help reduce $\mathrm{CO}_{2}$ emissions.

To ensure the efficiency of the economic sector, environmental tax rates, including $\mathrm{CO}_{2}$ emission charges, should be applied to all taxpayers and cover all energy products. However, well-established practice, while reflecting different environmental tax rates across the EU, demonstrates deviations from academic models and lack of harmonization [18].

The EU is the first and only region to pay energy taxes in all Member States. The most significant energy products are gasoline and diesel, which are the most intensively used for transport purposes, and are the energy base of many technological chains in different sectors of the economy (agriculture, construction, processing, and others). Energy products intended for stationary use include fuel oil, natural gas, coal, and electricity. Usually, the main objective of environmental taxes (including energy) is to generate revenue for the public sector. The data on the dynamics of the volumes of total environmental taxes (TET) consolidated indicators in the EU countries are presented in Table 1.

Two groups can be distinguished from the totality of countries, which, to some extent, polarize trends within the EU.

The first group of countries shows a downward trend in environmental taxes - the annual average of the total environmental tax revenue in these countries is below its base value in 2008 - or demonstrates a very low level of increasing them (less than 500 thousand euros during 10 years). These countries include Norway $(-156.2)$, Bulgaria, Cyprus, Luxembourg, Slovenia, Hungary, Croatia, Sweden, Iceland, Malta, Estonia, Latvia, and Lithuania. A characteristic feature of the group is the low cumulative share of these countries in the total mass of environmental tax revenues over the relevant time. It accounted for only $9.5 \%$ of the total revenue from all countries in 2018

Instead, the second group, consisting of the United Kingdom, Italy, Belgium, Germany, Finland, Switzerland, Spain, the Netherlands, Denmark, Austria, France and Poland, shows a clear upward trend in environmental taxes ranging from $8 \%$ (Denmark, Greece) and up to $66 \%$ (Switzerland). At the same time, this group of countries provided more than $80 \%$ of the total mass of environmental taxes during the same 10 -year period.

Thus, even though individual countries have different dynamics and diametrically opposite trends in environmental taxation, the EU demonstrates a clear tendency for total increase in environmental tax revenues at the expense of a much higher share of the second group countries. That is why, during 2008-2018, the average value of the annual amount of environmental taxes per EU-28 country increased steadily. Barely exceeding $€ 9.4$ billion in 2008, in 2018 this figure reached a point that already exceeded $€ 12.0$ billion.

The analysis of structural architectonics of the ratio of individual types of taxes in the total mass of their receipts shows the total dominance of energy taxes $-76.9 \%$. Transportation taxes in this structure are $19.8 \%$. The share of taxes on pollution and resource use is the smallest, amounting to $3.3 \%$ [20, 21]. However, the overall dynamics of tax revenues, estimated on the basis of the TET indicator, even with a sufficiently deep 
Environmental tax revenues in European countries in 2008-2018, thousands of euro [19-21]

\begin{tabular}{|c|c|c|c|c|c|c|}
\hline Countries & 2008 & 2010 & 2012 & 2014 & 2016 & 2018 \\
\hline Austria & 6911.3 & 6912.8 & 7655.4 & 7974.9 & 8384.1 & 8855.8 \\
\hline Belgium & 8081.1 & 8879 & 9735 & 10254.5 & 11572.4 & 12407.2 \\
\hline Bulgaria & 1227.8 & 1051.6 & 1136.2 & 1209.7 & 1418.9 & 1648.1 \\
\hline Croatia & 1369.7 & 1368.8 & 1124.9 & 1379.9 & 1625.9 & 1853.4 \\
\hline Cyprus & 574.2 & 534.4 & 502.5 & 532.1 & 531 & 589.4 \\
\hline Czech Republic & 3643.8 & 3577.4 & 3606.4 & 3281.3 & 3725.4 & 4507.9 \\
\hline Denmark & 10077 & 9768.8 & 10098.5 & 10621.6 & 11065.4 & 10924.8 \\
\hline Estonia & 382.5 & 431.6 & 489.1 & 533.1 & 645.2 & 708.9 \\
\hline Finland & 5028 & 5015 & 5949 & 5957 & 6709 & 6848 \\
\hline France & 36728 & 37695 & 40946 & 43716 & 50125 & 55949 \\
\hline Germany & 55257 & 55178 & 58198 & 58293 & 58442 & 59737 \\
\hline Greece & 4972 & 5978 & 6265 & 6628 & 6656 & 6823 \\
\hline Hungary & 2967.4 & 2706.8 & 2594.6 & 2621.7 & 2986.4 & 3142.6 \\
\hline Iceland & 117.8 & 150.2 & 168.9 & 180.8 & 228.3 & 279.7 \\
\hline Ireland & 4314.5 & 4103.9 & 4182.3 & 4641.7 & 5074.5 & 5066.8 \\
\hline Italy & 41857 & 44751 & 56251 & 58070 & 58735 & 57775 \\
\hline Latvia & 506.9 & 530.6 & 660.4 & 790.2 & 907.9 & 982.7 \\
\hline Lithuania & 533.5 & 512.2 & 548.1 & 633.9 & 747.9 & 899.8 \\
\hline Luxembourg & 986.3 & 958.5 & 1039.6 & 980.5 & 934.2 & 1029.4 \\
\hline Malta & 199.9 & 190.6 & 205.5 & 239.8 & 277.1 & 321.8 \\
\hline Netherlands & 22233 & 22310 & 21178 & 22216 & 23754 & 25832 \\
\hline Norway & 8251.2 & 8591.4 & 9262.5 & 8732.8 & 8044.2 & 8095 \\
\hline Poland & 9675.7 & 9846.8 & 10072.6 & 10581.9 & 11579.8 & 13500.4 \\
\hline Portugal & 4483.8 & 4361.6 & 3681.6 & 3932.1 & 4819.3 & 5270.5 \\
\hline Romania & 2487 & 2650.8 & 2667.5 & 3587.4 & 4120.9 & 4239.8 \\
\hline Slovakia & 1358.9 & 1418.1 & 1669.5 & 1863.5 & 2033 & 2232.7 \\
\hline Slovenia & 1119.7 & 1312.1 & 1389.1 & 1452.7 & 1563.9 & 1609.7 \\
\hline Spain & 18179 & 17672 & 16325 & 19344 & 20793 & 22066 \\
\hline Sweden & 9364.8 & 9977.1 & 10310.7 & 9544.2 & 10341.4 & 9815 \\
\hline Switzerland & 6272 & 7711 & 8840.4 & 8868.2 & 10316.2 & 10408.8 \\
\hline UK & 44788.3 & 45928.2 & 50910.7 & 55672.8 & 58266.2 & 56745.2 \\
\hline EU-28 + Iceland, Norway, UK, Switzerland & 254513.9 & 259692.7 & 278491.6 & 290880.9 & 309568.8 & 324636.7 \\
\hline Mean value per country, billion euros & 9.4 & 9.6 & 10.3 & 10.8 & 11.5 & 12.0 \\
\hline
\end{tabular}

chronology by country and structured by environmental tax groups (ET, TT, PT and RT) over a longer period of time, does not yet provide serious empirical evidence grounds for generalizations and assessing the level of effectiveness of the EU environmental tax system.

Effectiveness of environmental taxation: an empirical analysis. Environmental taxes are those designed to tax behavior that is harmful to the planet's health [22]. They are based on a simple principle - those who pollute need to pay.

As it can be seen from Table 2, according to the level of environmental taxation, all European countries can be divided into three groups:

1. Countries in which the share of environmental taxes reaches $10 \%$ or more of the total tax revenue (Slovenia, Latvia, Croatia, Greece).

2. Countries in which the share of environmental taxes ranges from 6 to $9 \%$ of the total tax revenue (the Netherlands, Cyprus, Estonia, Denmark, Bulgaria, Malta, Italy, Romania, the Czech Republic, Poland, Ireland, Hungary, Lithuania, Slovakia).
3. Countries in which the share of environmental taxes is $5 \%$ or less of the total tax revenue (Austria, Switzerland, Iceland, Spain, Norway, Belgium, Germany, Luxembourg, Sweden).

Table 2

Environmental taxation in European countries as a share of total tax revenue, $\%, 2018[20,21]$

\begin{tabular}{|c|c|c|}
\hline Group 1 & Group 2 & Group 3 \\
\hline $\begin{array}{l}\text { Slovenia }-12.4 \\
\text { Latvia }-11.4 \\
\text { Croatia }-10.9 \\
\text { Greece }-9.5\end{array}$ & $\begin{array}{l}\text { Netherlands }-8.6 \\
\text { Cyprus, Estonia }-8.3 \\
\text { Denmark, Bulgaria }-8.1 \\
\text { Malta, Italy }-7.9 \\
\text { Romania }-7.7 \\
\text { Czech Republic }-7.5 \\
\text { Poland, Ireland }-7.1 \\
\text { Hungary, Lithuania }-6.7 \\
\text { Slovakia }-6.3\end{array}$ & $\begin{array}{l}\text { Austria }-5.7 \\
\text { Switzerland }-5.6 \\
\text { Iceland, Spain }-5.3 \\
\text { Norway }-5.2 \\
\text { Belgium }-5.0 \\
\text { Germany }-4.6 \\
\text { Luxembourg }-4.4 \\
\text { Sweden }-4.3\end{array}$ \\
\hline
\end{tabular}


For a deeper economic assessment of the effectiveness of the environmental tax system, we applied the cross-correlation method between intervals by country. In assessing this type of connection, we sought to answer the hypothetical question of how and when changing (increasing or decreasing) the rates of different types of environmental taxes affects the pollution of the environment. In doing so, as the first time series, we used the dynamics of changes in the percentage (in percentage to the previous year) of various environmental taxes $(\triangle T E T, \triangle E T, \triangle T T, \triangle P T$ and $\triangle R T)$, assessing their impact on the time series of changes (in percent to the previous year), the indicators characterizing the state of environmental pollution $\left(\triangle \mathrm{CO}_{2}\right.$ - indicator of change in carbon dioxide content, $\triangle P M 2.5 \mathrm{mg}$ - indicator of change in the air content of small particulate matter fraction $2.5 \mathrm{mg}$ ) and such indicators as, $\triangle R E$ - indicator of change in the share of renewable energy in ultimate consumption) with a time lag of -10 to +10 years.

Interpretation of the results of cross-correlation analysis revealed the possibility of a "mirror hypothesis" of the relationship between interval series of different countries. On the one hand, in the case of a significant cross-correlation coefficient for a negative lag, we tested the hypothesis that the deterioration (improvement) of a particular characteristic of the environmental condition was considered as a probable cause of a further change in the country's environmental tax rates. On the other hand, in the case of a significant cross-correlation coefficient for a positive lag value, we evaluated an alternative hypothesis, in which changes in tax rates with a certain time lag affected the country's environment.

The results obtained illustrate the high probability of diametrically opposite relationships between the studied variables for different groups of countries. In general, depending on the time lag symbol and the direction of cross-correlation, there are four groups of countries (Table 3 ).

The $1^{\text {st }}$ cluster includes countries in which environmental policy instruments such as air pollution fees and resource use charges are quite effective (Poland, Slovakia, Slovenia, Estonia).

The $2^{\text {nd }}$ cluster includes countries in which the environmental tax increase was accompanied by an increase in $\mathrm{CO}_{2}$ emissions (Belgium, the Czech Republic, Finland, Hungary). In the $3^{r d}$ group of countries, deterioration of the environmental situation is not a motivator for increasing the environmental taxation burden (Lithuania, Greece). The $4^{\text {th }}$ cluster demonstrates that deterioration of the environmental situation in the country motivates to increase the environmental taxation burden (Bulgaria, Spain). Groups 1 and 2 can also be attrib-

Table 3

Country's clusters by effectiveness, motivation, and impact of environmental policy instruments

\begin{tabular}{|c|c|c|c|}
\hline & \multicolumn{2}{|c|}{ Cross-correlation coefficient symbol } \\
\hline & & - & + \\
\hline \multirow{2}{*}{ 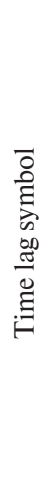 } & + & $\begin{array}{l}\text { (I) } \\
\text { Increasing the burden of } \\
\text { environmental taxation in the } \\
\text { country causes an improvement } \\
\text { in the environmental situation } \\
\text { in the country with a time lag } t \\
\text { (effective environmental policy } \\
\text { instrument) }\end{array}$ & $\begin{array}{l}\text { (II) } \\
\text { Increasing the burden of } \\
\text { environmental taxation in } \\
\text { the country does not } \\
\text { improve the environmental } \\
\text { situation in the country } \\
\text { (ineffective environmental } \\
\text { policy instrument) }\end{array}$ \\
\hline & - & $\begin{array}{l}\text { (III) } \\
\text { Deterioration of the } \\
\text { environmental situation is not } \\
\text { a motivator for increasing the } \\
\text { environmental taxation } \\
\text { burden }\end{array}$ & $\begin{array}{l}\qquad(\mathbf{I V}) \\
\text { Deterioration of the } \\
\text { environmental situation in } \\
\text { the country motivates to } \\
\text { increase environmental } \\
\text { taxation burden }\end{array}$ \\
\hline
\end{tabular}

uted to countries characterized by significant cross-correlation coefficients for $t=0$. For such countries, there is a reactive change in the ecological status after an increase in environmental tax revenues.

According to the results of the cross-correlation analysis of time series $\triangle P T$ and $\triangle P M 2.5 \mathrm{mg}$, the first cluster is assigned to Poland $\left(r_{\text {cross }}=-0.783, t=2\right)$, Slovakia $\left(r_{\text {cross }}=-0.825, t=1\right)$, Slovenia $\left(r_{\text {cross }}=-0.671, t=0\right)$ (Fig. 1$)$, and for $\Delta R T$ and $\Delta \mathrm{CO}_{2}-$ Estonia $\left(r_{\text {cross }}=-0.487, t=1\right)$ and Poland $\left(r_{\text {cross }}=\right.$ $=-0.852, t=0)$ (Fig. 2). This demonstrates that environmental policy instruments such as air pollution fees and resource use charges are quite effective in these countries.

Belgium, the Czech Republic, Finland $(t=1)$, Hungary ( $t=$ 2 ) are in the second group of countries. The positive value of the cross-correlation coefficients and their statistical significance for all countries of this group indicates that the tax increase was accompanied by an increase in $\mathrm{CO}_{2}$ emissions (Fig. 3).

Second cluster also includes countries with significant positive cross-correlation at zero-time lag. According to the analysis of time series reflecting the dynamics of TET and $\mathrm{CO}_{2}$, this cluster also includes Ireland (cross-correlation coefficient is 0.4960), Luxembourg (0.7257), Sweden (0.5232) (Fig. 4). Cross-correlation of the interval series $\Delta E T$ and $\Delta R E$ also revealed three countries with similar patterns - Estonia (0.4842), Greece (0.5089), Romania (0.5088).

It should be noted that in the short term, in this group of countries statistically significant and illogical, at first glance, dependence between all types of taxes and indicators of environmental pollution was revealed, namely the increase in environmental tax burden was accompanied by an increase in the amount of harmful emissions. It is important to note that seven countries in this group (Ireland, Luxembourg, Estonia, Cyprus, Croatia, Hungary and Slovenia) are countries with an area of up to $100.000 \mathrm{~km}^{2}$, which makes their contribution to the overall pollutant emissions not too weighty. This illogical, in our opinion, dependency is also conditioned by the "help" of not only

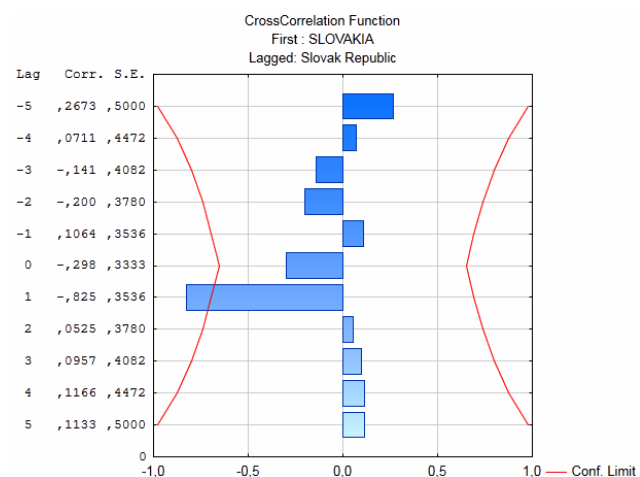

Fig. 1. Cross-correlation coefficients between time series reflecting of $\triangle P T$ and $\triangle P M 2.5 \mathrm{mg}$ dynamics in Slovakia [20, 21]

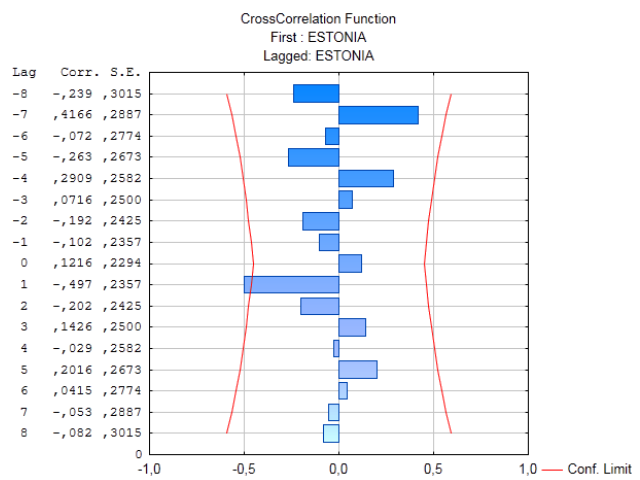

Fig. 2. Cross-correlation coefficients between time series reflecting of $\triangle R T$ and $\triangle \mathrm{CO}_{2}$ dynamics in Estonia $[20,21]$ 


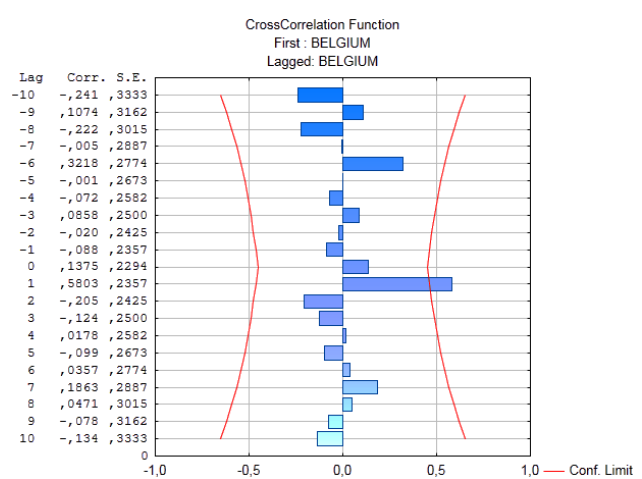

Fig. 3. Cross-correlation coefficients between time series reflecting of $\triangle T E T$ and $\triangle \mathrm{CO}_{2}$ dynamics in Belgium [20,21]

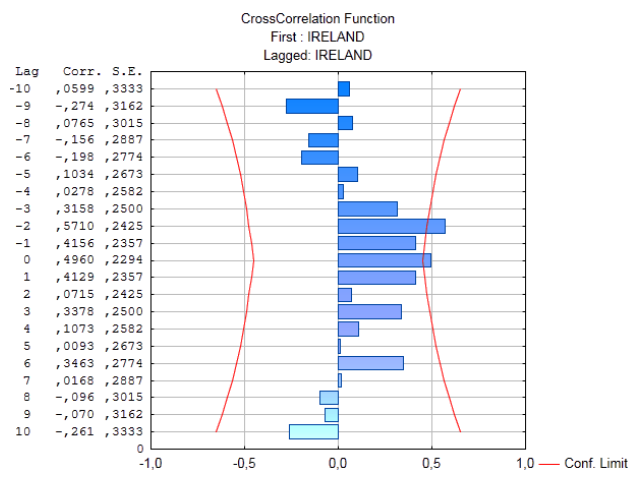

Fig. 4. Cross-correlation coefficients between time series reflecting of $\triangle T E T$ and $\triangle \mathrm{CO}_{2}$ dynamics in Ireland [20, 21]

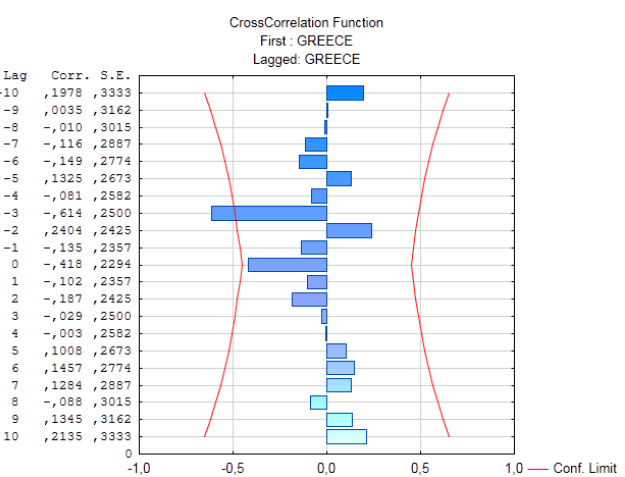

Fig. 5. Cross-correlation coefficients between time series reflecting of $\triangle T E T$ and $\triangle \mathrm{CO}_{2}$ dynamics in Greece [20, 21]

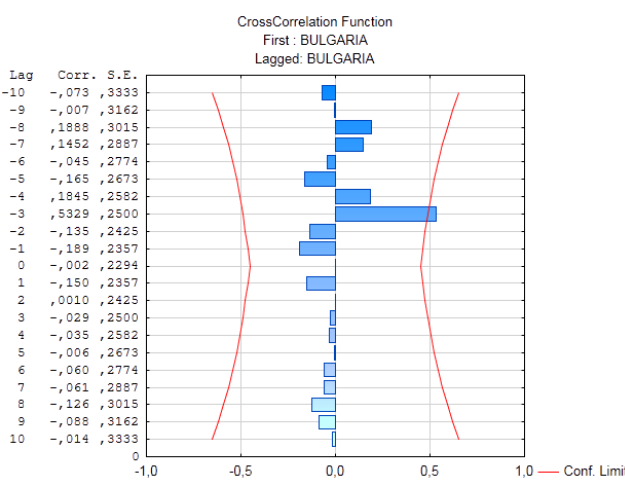

Fig. 6. Cross-correlation coefficients between time series reflecting the dynamics of $\triangle T E T$ and $\triangle \mathrm{CO}_{2}$ in Bulgaria $[20,21]$ neighboring countries but also, above all, the contribution of the main generators of pollution - the USA, China, and Russia.

In the third group of countries, there is a ratio of intervals, in which the first series reflects the dynamics of carbon dioxide emissions $\left(\Delta \mathrm{CO}_{2}\right)$, whereas the lag series shows the change in the sums of all environmental taxes $(\triangle T E T)$. This cluster includes Greece $(t=-3)$ and Lithuania $(t=-2)$, which are characterized by negative cross-correlation coefficients between the series of the above indicators (Fig. 5).

Fourth cluster can be attributed to Bulgaria $(t=-3)$ and Spain $(t=-1)$, in which the increase in $\mathrm{CO}_{2}$ emissions caused fiscal reflection in the form of increased environmental tax pressure (Fig. 6).

It should be noted that there is a separate group of countries for which several significant cross-correlation coefficients are found in certain pairs of time series in both negative and positive time lags. According to the results of the cross-correlation analy-

Table 4

Statistically significant cross-correlation coefficients between time series of environmental tax dynamics and environmental pollution indicators [20-22]

\begin{tabular}{|c|c|c|c|c|c|}
\hline \multicolumn{3}{|c|}{ Negative lag } & \multicolumn{3}{|c|}{ Positive or zero lag } \\
\hline Country & 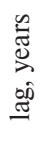 & 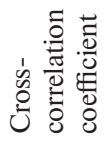 & Country & 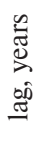 & 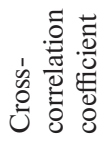 \\
\hline \multicolumn{6}{|c|}{ Cross-correlation of time series $\triangle T E T$ and $\triangle \mathrm{CO}_{2}$} \\
\hline Bulgaria & -3 & 0.5329 & Belgium & 1 & 0.5803 \\
\hline Spain & -1 & 0.5707 & Czech Republic & 1 & 0.5113 \\
\hline Finland & -1 & -0.536 & Finland & 1 & 0.5344 \\
\hline Greece & -3 & -0.614 & Hungary & 2 & 0.4985 \\
\hline Hungary & -4 & -0.590 & Ireland & 0 & 0.4960 \\
\hline Ireland & -2 & 0.571 & Luxembourg & 0 & 0.7257 \\
\hline Lithuania & -2 & -0.532 & Sweden & 0 & 0.5232 \\
\hline \multicolumn{6}{|c|}{ Cross-correlation of time series $\Delta E T$ and $\Delta R E$} \\
\hline UK & -6 & -0.569 & Austria & 1 & -0.472 \\
\hline Greece & -3 & 0.5792 & Switzerland & 1 & 0.4483 \\
\hline Hungary & -1 & -0.545 & Czech Republic & 1 & -0.599 \\
\hline \multirow[t]{4}{*}{ Croatia } & -1 & -0.471 & Estonia & 0 & 0.4842 \\
\hline & & & France & 3 & 0.6270 \\
\hline & & & Greece & 0 & 0.5089 \\
\hline & & & Romania & 0 & 0.5088 \\
\hline \multicolumn{6}{|c|}{ Cross-correlation of time series $\Delta T T$ and $\Delta \mathrm{CO}_{2}$} \\
\hline Spain & -1 & 0.6789 & Cyprus & 1 & 0.5545 \\
\hline Croatia & -1 & 0.6600 & Luxembourg & 3 & 0.5493 \\
\hline Greece & -1 & 0.4883 & Spain & 1 & 0.6272 \\
\hline Italy & -4 & 0.6044 & Finland & 0 & 0.4812 \\
\hline Sweden & -1 & -0.582 & Lithuania & 1 & -0.4900 \\
\hline \multirow[t]{5}{*}{ France } & -1 & -0.497 & Croatia & 1 & 0.4911 \\
\hline & & & Ireland & 0 & 0.5448 \\
\hline & & & Greece & 1 & 0.4564 \\
\hline & & & Hungary & 0 & 0.4744 \\
\hline & & & Italy & 1 & 0.4926 \\
\hline \multicolumn{6}{|c|}{ Cross-correlation of time series $\triangle P T$ and $\triangle P M 2.5 \mathrm{mg}$} \\
\hline & & & Poland & 2 & -0.783 \\
\hline & & & Slovakia & 1 & -0.825 \\
\hline & & & Slovenia & 0 & -0.671 \\
\hline \multicolumn{6}{|c|}{ Cross-correlation of time series $\Delta R T$ and $\Delta \mathrm{CO}_{2}$} \\
\hline Finland & -2 & 0.4858 & Estonia & 1 & -0.497 \\
\hline & & & Poland & 0 & -0.852 \\
\hline
\end{tabular}


sis of $\triangle T E T$ and $\triangle \mathrm{CO}_{2}$ time series, these countries are Finland, Hungary and Ireland; $\Delta E T$ and $\Delta R E$ time series - Greece; and $\Delta T T$ and $\Delta \mathrm{CO}_{2}$ time series - Spain, Croatia, Greece and Italy.

The summary data of the cross-correlation analysis are given in Table 4. There were made five types of cross-correlation analysis: between $\triangle T E T$ and $\triangle \mathrm{CO}_{2}$; between $\triangle E T$ and $\triangle R E$; between $\triangle T T$ and $\triangle \mathrm{CO}_{2}$; between $\triangle P T$ and $\triangle P M 2.5 \mathrm{mg}$; between $\triangle R T$ and $\Delta \mathrm{CO}_{2}$.

Conclusions. The growing demand for the public good "clean ecology" raises the question of how the economy with the given technological parameters can provide it. In this sense, environmental taxes should be corrective, and their fiscal role should "take a back seat" [19].

However, the analysis of environmental tax revenues in European countries (in terms of volume and structure) showed the dominance of their fiscal component. The most important instruments of environmental policy in EU countries are energy and transport taxes, the collection of which is mainly aimed at preventing climate changes.

Despite the statistically significant results obtained for individual pairs of interval series and for individual countries, the study does not provide enough grounds for a general systematic assessment and, accordingly, requires an expansion of the initial empirical base and further in-depth analytics. The data obtained indirectly indicate that the dependencies between the time series we investigated are likely to be nonlinear in nature, which the found cross-correlation coefficients cannot detect.

It is also necessary to emphasize here some limitations and shortcomings of our analytical approach to assessing the problem under study:

- firstly, the peculiarity of the greenhouse gas problem lies in their enormous circulatory and convection capacity, and the volumes, such as $\mathrm{CO}_{2}$, which European countries are trying to reduce through their fiscal instruments, are abundantly offset by the US, China and Russia;

- secondly, the "taxes-pollution" (or "pollution-taxes") model is also limited because it does not take into account many other potentially important explanatory variables (GDP, amount and density of population, levels of poverty and environmental culture in countries, dynamics of forest areas and green spaces, etc.).

Acknowledgement. The authors acknowledged that the study was conducted within the [Project 0117U000412] "Ecologization in a new paradigm of welfare state" 2017-2019.

\section{References.}

1. European Environment Agency (2010). Environmental Taxes: Recent Developments in Tools for Integration. Retrieved from http://edz.bib.uni-mannheim.de/daten/edz-bn.

2. Pigou, A.C. (2013). The Economics of Welfare. London: Palgrave Macmillan. https://doi.org/10.1057/978-1-13737562-9.

3. Merko, F., Dursun, S., \& Merko, F. (2018). Environmental Taxation - the Efects on Environmental Effectiveness and Economic Efficiency. International Journal of Ecosystems and Ecology Science, 8(4), 739-746. https://doi.org/10.31407/ijees84.

4. He, P., Zhang, Y., Yuan, Y., Qiao, Y., Xin, L., \& Zou, X. (2019). The Relationship between Environmental Taxation, Environmental Performance and Economic Growth: Comparative Study of Sweden and China 1985-2016. Ekoloji, 28(107), 401-410.

5. Kuralbayeva, K. (2019). Environmental Taxation, Employment and Public Spending in Developing Countries. Environmental \& Resource Economics, 72(4), 877-912. https://doi. org/10.1007/s10640-018-0230-3.

6. Vandyck, T., \& van Regemorter, D. (2014). Distributional and regional economic impact of energy taxes in Belgium. Energy Policy, 72, 190-203. https://doi.org/10.1016/i.enpol.2014.04.004. 7. Wiesmeth, H., \& Marquardt, J. (2013). Environmental Economics. Theory and Policy Equilibrium. Berlin, Heidelberg: Springer-Verlag. ISBN 9783642270420.
8. Costantini, V., \& Mazzanti, M. (2012). On the Green and Innovative Side of Trade Competitiveness? The Impact of Environmental Policies and Innovation on EU Exports. Elsevier Research Policy, 41, 132-153. https://doi.org/10.1016/j.respol.2011.08.004. 9. Anita, S., Capasso, V., Kunze, H., \& la Torre, D. (2016). Optimizing Environmental Taxation on Physical Capital for a Spatially Structured Economic Growth Model Including Pollution Diffusion. Vietnam Journal of Mathematics, 45, 199206. https://doi.org/10.1007/s10013-016-0215-X.

10. Houdek, P., \& Koblovsky, P. (2015). Where is My Money? New Findings in Fiscal Psychology. Society, 52, 155-158. https://doi.org/10.1007/s12115-015-9873-7.

11. Lutsyshyn, Z., Klapkiv, Y., Kucher, T., \& Svirskyi, V. (2019). Development of innovative instruments in the financial market of Ukraine. Revista Espacios, 40(28), 22-37.

12. Alvarez, M. (2019). Distributional effects of environmental taxation: an approximation with a meta-regression analysis. Economic Analysis and Policy, 62(C), 382-401. https://doi. org/10.1016/i.eap.2018.10.003.

13. Freire-González, J. (2018). Environmental taxation and the double dividend hypothesis in CGE modelling literature: a critical review. Journal of Policy Modeling, 40(1), 194-223. https://doi.org/10.1016/j.jpolmod.2017.11.002.

14. Bento, A., \& Jacobsen, M. (2007). Ricardian rents, environmental policy and the "double-dividend" hypothesis. Journal of Environmental Economics and Management, 53(1), 17-31. https://doi.org/10.1016/j.jeem.2006.03.006.

15. Fullerton, D., Leicester, A., \& Smith, S. (2010). Environmental Taxes. Oxford: Oxford University Press. https://doi. org/10.3386/w14197.

16. Heine, D., Norregaard, J., \& Parry, W.H. (2012). Environmental Tax Reform: Principles from Theory and Practice to Date. IMF Working Papers, 180. https://doi. org/10.5089/9781475505283.001.

17. Institute for European Environmental Policy (IEEP) (2013). Final Report. Evaluation of Environmental Tax Reforms: International Experiences. Retrieved from http://www.efv.admin.ch/e/downloads.

18. European Commission (2013). Tax Reforms in EU Member States 2013 of European Commission. Retrieved from http:// ec.europa.eu/taxation_customs.

19. Koziuk, V., Shymanska, O., \& Voznyi, K. (2019). Environmental taxation trends in Europe. World of Finance, 4(61), 8-22. 20. EUROSTAT (2019). Environmental tax statistics. Retrieved from https://ec.europa.eu/eurostat.

21. Environmental tax revenues (2020). Retrieved from https://appsso.eurostat.ec.europa.eu/nui.

22. Environmental taxes make way to protect the environment (2018). Retrieved from https://www.iberdrola.com/environment/green-and-environmental-taxes.

\section{Ефективність екологічного оподаткування в європейських країнах: порівняльний аналіз}

\section{В. В. Козюк ${ }^{1}$, Ю. І. Гайда ${ }^{1}$, О. В. Длугопольський ${ }^{1}$ В. П. Мартинюк ${ }^{2}$ Ю. М. Клапків ${ }^{3}$}

1 - Тернопільський національний економічний університет, м. Тернопіль, Україна, e-mail: dlugopolsky77@gmail.com $2-$ Університет економіки та інновацій (WSEI), м. Люблін, Польща

3 - Університет Лодзький, м. Лодзь, Польща

Мета. Проведення економічної оцінки ефективності системи екологічного оподаткування в європейських країнах. Сформульована авторами гіпотеза стосується того, як і коли зміни у ставках різних видів екологічних податків впливають на обсяги забруднення навколишнього середовища.

Методика. Для економічної оцінки ефективності системи екологічного оподаткування у роботі використову- 
ється метод перехресної кореляції між окремими показниками в розрізі країн Европи.

Результати. Ефективність екологічних податків залежить від податкової бази, податкових ставок, еволюції податків і податкової політики. Архітектура екологічних податків і особливості їх застосування в різних країнах Європи суттєво відрізняються. Загалом, можна виділити дві групи країн ЕС з огляду на полярні тенденції в розвитку екологічного оподаткування. Перша група країн демонструє тенденцію до зменшення екологічних податків - середньорічна загальна сума доходів від екологічних податків у цих країнах сьогодні нижче їі базової суми у 2008 р. (Болгарія, Кіпр, Норвегія, Люксембург, Словенія, Угорщина, Хорватія, Швеція, Ісландія, Мальта, Естонія, Латвія, Литва). Друга група країн демонструє чітку тенденцію до зростання екологічних податків (Данія, Греція, Швейцарія, Великобританія, Італія, Бельгія, Німеччина, Фінляндія, Іспанія, Нідерланди, Австрія, Франція, Польща).

Наукова новизна. Залежно від значення часового відставання й напряму перехресної кореляції, можна виокремити чотири кластери країн ЕС в контексті впливу екологічної політики. До першого кластеру входять країни, в яких інструменти екологічної політики (плата за забруднення повітря, плата за використання ресурсів) є досить ефективними (Польща, Словаччина, Словенія, Естонія). До другого кластеру належать країни, в яких підвищення податку на навколишнє середовище супроводжується збільшенням викидів $\mathrm{CO}_{2}$ (Бельгія, Чехія, Фінляндія, Угорщина). У третій групі країн погіршення екологічної ситуації не є мотиватором для збільшення навантаження у вигляді екологічних податків (Литва, Греція). Четвертий кластер країн демонструє, що погіршення екологічної ситуації у країні мотивує до збільшення навантаження у вигляді екологічних податків (Болгарія, Іспанія).

Практична значимість. Отримані дані вказують на те, що залежність між досліджуваними часовими рядами $є$ ймовірно нелінійною за своєю природою, яку перехресні кореляційні коефіцієнти не можуть виявити. Проведене дослідження та отримані результати демонструють високу ймовірність існування діаметрально протилежних взаємозалежностей між досліджуваними змінними для різних груп європейських країн.

Ключові слова: екологічне оподаткування, екологічна політика, економічне зростання, держави - члени $Е C$

\section{Эффективность экологического налогообложения в европейских странах: сравнительный анализ}

\section{В. В. Козюк ${ }^{1}$, Ю. И. Гайда ${ }^{1}$, А. В. Длугопольский ${ }^{1}$, В. П. Мартынюк ${ }^{2}$ Ю. М. Клапкив ${ }^{3}$}

1 - Тернопольский национальный экономический университет, г. Тернополь, Украина, e-mail: dlugopolsky77@ gmail.com

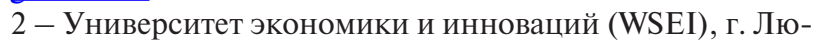
блин, Польша

3 - Университет Лодзкий, г. Лодзь, Польша
Цель. Проведение экономической оценки эффективности системы экологического налогообложения в странах Европы. Сформулированная авторами гипотеза касается того, как и когда изменения в ставках различных видов экологических налогов влияют на объемы загрязнения окружающей среды.

Методика. Для экономической оценки эффективности системы экологического налогообложения в работе используется метод перекрестной корреляции между отдельными показателями в странах Европы.

Результаты. Эффективность экологических налогов зависит от налоговой базы, налоговых ставок, эволюции налогов и налоговой политики. Архитектура экологических налогов и особенности их применения существенно различаются в пределах отдельных стран Европы. Проведенное исследование позволило выделить две группы стран Европы, учитывая полярные тенденции в развитии экологического налогообложения. Первая группа демонстрирует тенденцию к уменьшению экологических налогов - среднегодовая общая сумма доходов от экологических налогов в этих странах сегодня ниже ее базовой суммы в 2008 г. (Болгария, Кипр, Норвегия, Люксембург, Словения, Венгрия, Хорватия, Швеция, Исландия, Мальта, Эстония, Латвия, Литва). Вторая группа стран демонстрирует четкий тренд роста экологических налогов (Дания, Греция, Швейцария, Великобритания, Италия, Бельгия, Германия, Финляндия, Испания, Нидерланды, Австрия, Франция, Польша).

Научная новизна. В зависимости от значения временного отставания и направления перекрестной корреляции, можно выделить четыре кластера европейских стран в контексте влияния экологической политики. К первому кластеру относятся страны, в которых инструменты экологической политики (плата за загрязнение воздуха, плата за использование ресурсов) являются достаточно эффективными (Польша, Словакия, Словения, Эстония). Ко второму кластеру относятся страны, в которых повышение ставок экологических налогов сопровождается увеличением выбросов $\mathrm{CO}_{2}$ (Бельгия, Чехия, Финляндия, Венгрия). В третьей группе стран ухудшение экологической ситуации не является мотиватором для увеличения нагрузки в виде экологических налогов (Литва, Греция). Четвертый кластер стран демонстрирует, что ухудшение экологической ситуации в стране мотивирует к увеличению экологической налоговой нагрузки (Болгария, Испания).

Практическая значимость. Полученные данные указывают на то, что зависимость между исследуемыми временными рядами является, вероятно, нелинейной по своей природе, которую перекрестные корреляционные коэффициенты не позволяют обнаружить. Проведенное исследование и полученные результаты демонстрируют высокую вероятность существования диаметрально противоположных взаимозависимостей между исследуемыми переменными для различных групп европейских стран.

Ключевые слова: экологическое налогообложение, экологическая политика, экономический рост, государства члены $Е C$

Recommended for publication by Tomasz Wolowiec, Doctor hab. The manuscript was submitted 12.04.20. 